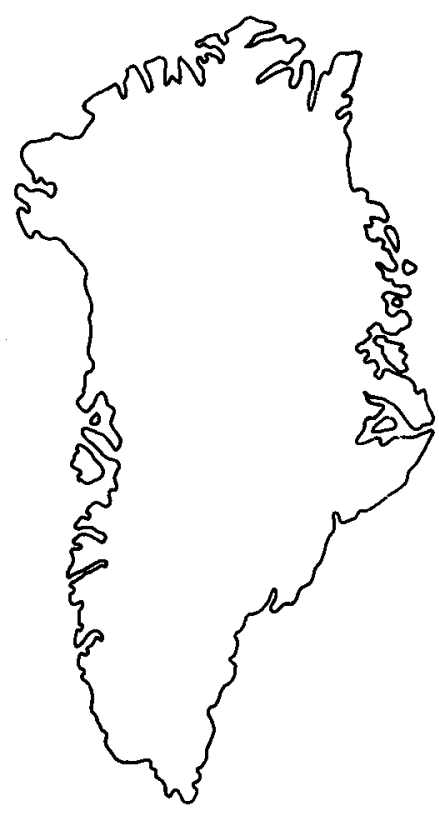

\title{
Stratigraphic significance of new fusulinid samples from the Upper Palaeozoic Mallemuk Mountain Group, North Greenland
}

\author{
Inger Nilsson, Eckart Håkansson, Lena Madsen, \\ Stig A. Schack Pedersen and Lars Stemmerik
}

\begin{abstract}
Dating of new fusulinid samples from the Mallemuk Mountain Group has improved constraints on age control of the regional lithostratigraphic units. Sediments of Late Carboniferous age are reported for the first time in Kronprins Christian Land where also the first recorded Sakmarian fusulinids have been found. The base of the Kim Fjelde Formation in Amdrup Land has been dated as Moscovian; this is slightly older than previous age assignments.

I. N., Institutt for Kontinentalsokkelunders $\emptyset$ kelser og Petroleumsteknologi (IKU), S. P. Andersens vei $15 B, N$-7034 Trondheim, Norway.

E. H. \& L. M., Institute of Historical Geology and Palaeontology, Øster Voldgade 10, DK-1350 Copenhagen K, Denmark.

S. A. S. P., Geological Survey of Denmark, Thoravej 8, DK-2400 Copenhagen NV, Denmark.

L. S., Geological Survey of Greenland, Øster Voldgade 10, DK-1350 Copenhagen K, Denmark.
\end{abstract}

Biostratigraphic control is limited in most Upper Palaeozoic strata in central and eastern North Greenland (Fig. 1) due to the sporadic occurrence of suitable fossils such as fusulinid foraminifera (cf. Stemmerik \& Håkansson, 1989). In combination with the superficial monotony of the carbonates throughout the area, this situation provides a major obstacle to detailed correlations across structural boundaries in this highly tectonised region (Håkansson \& Pedersen, 1982; Håkansson \& Stemmerik, 1989).

The ages of the lithostratigraphic units given by Stemmerik \& Håkansson (1989) are mainly based on older biostratigraphic work of Dunbar et al. (1962) and Petryk (1977) with some additional fusulinid dates from J. E. Whittaker (in Stemmerik \& Håkansson, 1989). To improve constraints on these ages eleven additional fusulinid bearing samples collected during field work in 1978, 1980 and 1988 (Håkansson, 1979; Håkansson et al., 1981, 1989) have been dated. Most samples are from Prinsesse Ingeborg Halvø and allow a more precise dating of the sediments there than has previously been possible. Samples from Peary Land and southern Amdrup Land mainly confirm previous age assignments while a single sample from northern Amdrup Land dates the carbonates there as Moscovian. These sediments were previously believed to be of early Permian age.

The new fusulinid data presented here only focus on the stratigraphic implications of the fauna; the systematic description of the fusulinids will be reported elsewhere (I. Nilsson, unpublished data).

\section{Prinsesse Ingeborg Halvø}

A number of samples from the lower part of the thick Upper Palaeozoic sequence described by Håkansson et al. (1989) were investigated. Geological Institute, University of Copenhagen (GI) samples 72168, 72370 and 72371 contained a poorly preserved fauna of Triticites sp.; the morphological simplicity of the specimens indicates a Late Carboniferous age i.e. Kasimovian-Gzhelian.

The remaining samples from this area all included a more diversified fauna of Early Permian age as listed and discussed below. 

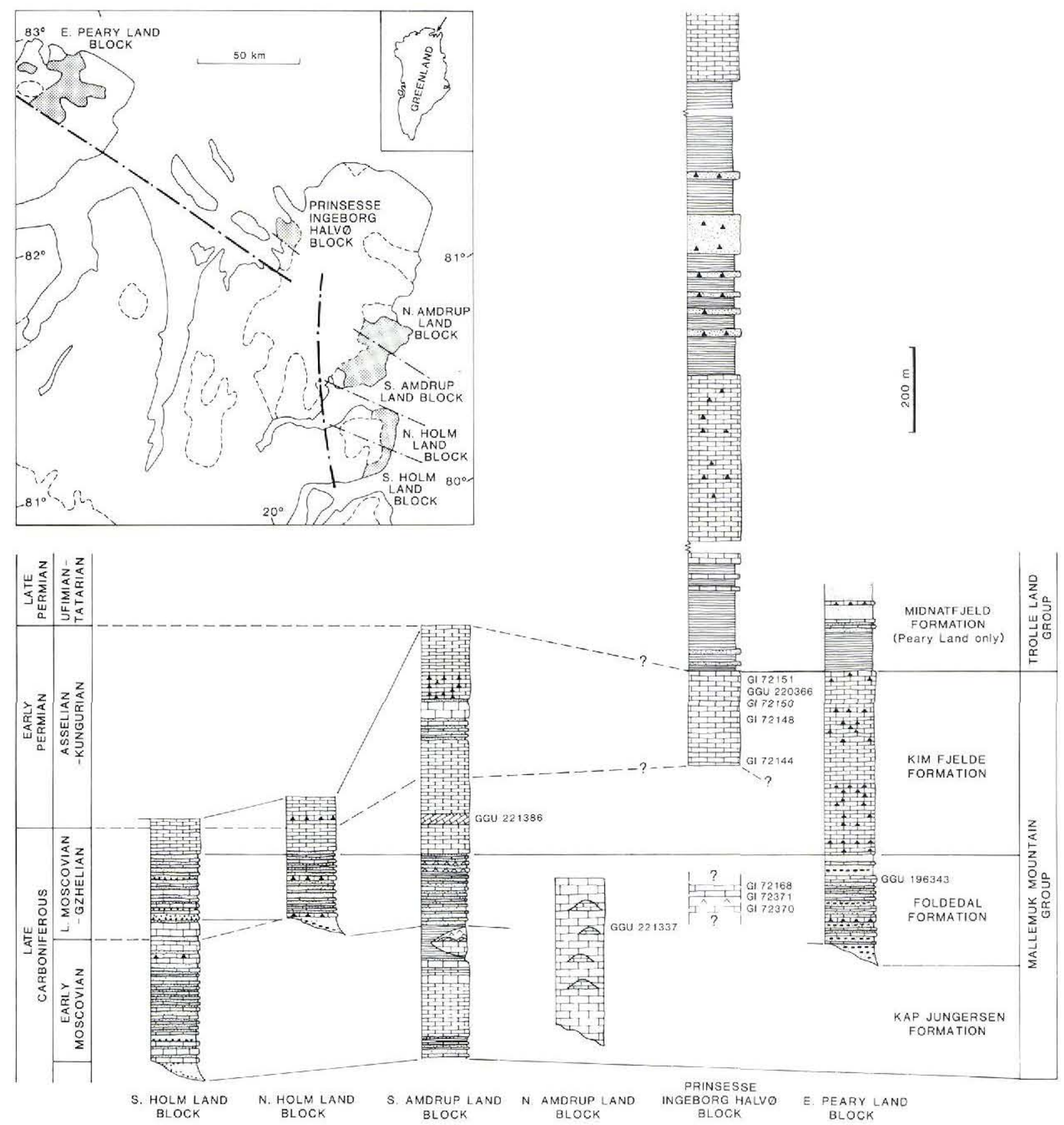

Fig. 1. Lithostratigraphic correlation of marine Upper Palaeozoic sediments in North Greenland with position of dated samples. Solid lines indicate lithostratigraphic units; dotted lines are proposed biostratigraphic correlation (based on Håkansson \& Stemmerik, 1984; Stemmerik \& Håkansson, 1989). Inset map shows distribution of Upper Palaeozoic sediments.

\section{GI sample 72144}

Schwagerina ex. gr. S. princeps (Ehrenberg) Dunbar \& Skinner

Schwagerina sp. A

Pseudofusulinella sp.
This fauna can be correlated to the Schwagerina princeps assemblage zone defined on Svalbard, and is thus of middle to late Asselian age (Nilsson, 1988). 
GI sample 72148

Schwagerina cf. S. moelleri (Schellwien) Dunbar \& Skinner

Schubertella transitoria Staff \& Wedekind

$S$. moelleri is regarded as being of early Sakmarian age by comparison to the zonation established in the Timan-Pechora basin of the USSR by Grozdilova \& Lebedeva (1961).

\section{GI sample 72150}

Sphaeroschwagerina sp.

Schwagerina cf. S. vulgaris (Schellwien \& Dyrenfurth) Dunbar \& Skinner

Schwagerina ex. gr. S. princeps (Ehrenberg) Dunbar \& Skinner

Schwagerina sp.

Pseudofusulinella sp.

\section{GGU sample 220366}

Sphaeroschwagerina sp.

Schwagerina cf. S. globosa (Schellwien \& Dyrenfurth) Dunbar \& Skinner

Schwagerina ex. gr. S. princeps (Ehrenberg) Dunbar \& Skinner

Schwagerina sp.

The fauna of these two samples is regarded as being of late Asselian to early Sakmarian age by comparison with the zonation in the Timan-Pechora basin, USSR, established by Grozdilova \& Lebedeva (1961). The fauna is younger than that described from GI sample 72144 , and thus contemporaneous with, or younger than the youngest part of the $S$. princeps assemblage zone on Svalbard (Nilsson, 1988). The occurrence of $S$. cf. $S$. moelleri stratigraphically below supports an early Sakmarian age for this fauna.

GI sample 72151 from stratigraphically younger strata contained only an advanced species of Schwagerina, and may be of even younger Sakmarian age (Fig. 1).

\section{Peary Land}

GGU sample 196343 from the Foldedal Formation (Stemmerik \& Håkansson, 1989; Fig. 1) contains the following species.

Triticites rossicus (Schellwien) Rauser-Chernoksova

Quasifusulina cf. Q. eleganta Schlykova

?Schwagerina (?)arctica (Schellwien) Nilsson

Triticites sp. A
This fauna is dated as Gzhelian on the basis of the simplicity of the Triticites.

\section{Amdrup Land}

GGU sample 221386 from the lower part of the Kim Fjelde Formation (Stemmerik \& Håkansson, 1989; Fig. 1) was found to contain a fauna of:

Wedekindellina dutkevichi Rauser-Chernousova \& Beljaev

Beedeina paradistenta (Safonova) Jshii

Fusulinella cf. F. bocki Möller

Taitzehoella librovitchi (Dutkevich) Sheng

This fauna can be correlated with the late Moscovian Wedekindellina zone of Dunbar et al. (1962) on the basis of the occurrence of $W$. dutkevichi (Ross \& Dunbar, 1962). This age is slightly older than that suggested previously for the Kim Fjelde Formation (Stemmerik \& Håkansson, 1989).

\section{Northern Amdrup Land}

GGU sample 221337 from the upper part of the sediments in northern Amdrup Land was found to contain a specimen of Fusulinella sp. This indicates a Moscovian age for these sediments, previously thought to be of early Permain age (cf. Stemmerik \& Håkansson, 1989).

\section{Stratigraphic implications}

The fusulinid faunas found in GI samples 72168 , 72370 and 72371 from Prinsesse Ingeborg Halvø represent the first conclusive evidence of Upper Carboniferous sediments in Kronprins Christian Land. The samples all originate from disconnected units in a tectonic mélange along the southern boundary fault on the peninsula and, at present, no data on thickness or depositional environment can be given (Håkansson et al., 1989). However, in this tectonic mélange the carbonates are associated with units of gypsum which, outside this area, are known from the Moscovian Kap Jungersen Formation. Depositional conditions similar to those inferred for this formation by Stemmerik \& Håkansson, (1989) may therefore have occurred also on Prinsesse Ingeborg Halvø. This hypothesis is further substantiated by dating of the carbonates on the north Amdrup Land block as Moscovian.

The Gzhelian age obtained from GGU sample 196343 confirm previous age assignments for the Foldedal Formation in the Peary Land region (Håkansson \& Stemmerik, 1989; Stemmerik \& Håkansson, 1989). The Mos- 
covian age for the lower part of the Kim Fjelde Formation, indicated by the fauna in GGU sample 221386, places the transition from mixed carbonate and siliciclastic deposition to monotonous carbonate platform sedimentation at an earlier time than previously thought (see Håkansson \& Stemmerik, 1989, fig. 2; Stemmerik \& Håkansson, 1989, fig. 2).

The Early Permian ages obtained from GI samples 72144, 72148, 72150, 72151 and GGU sample 220366 confirm the age assignment given previously by Håkansson \& Stemmerik (1989) and Stemmerik \& Håkansson (1989). However, the new data provide a more precise date for the upper parts of the Kim Fjelde Formation than anywhere else in North Greenland (Fig. 1).

\section{References}

Dunbar, C. O. Troelsen, J. [C.], Ross, C. A., Ross, J. P. \& Norford, B. 1962: Faunas and correlation of the Late Paleozoic rocks of Northeast Greenland. Part I. General discussion and summary. Meddr Grønland 167(4), 16 pp.

Grozdilova, L. P. \& Lebedeva, N. S. 1961: Nizhepermiskie foraminifery severnogo Timana. Microfauna SSSR, Sb. 13. Trudy VNIGRI 179, 161-283.

Håkansson, E. 1979: Carboniferous to Tertiary development of the Wandel Sea Basin, eastern North Greenland. Rapp. Grønlands geol. Unders. 88, 72-83.
Håkansson, E. \& Pedersen, S. A. S. 1982: Late Paleozoic to Tertiary tectonic evolution of the continental margin in North Greenland. In Embry, A. F. \& Balkwill, H. R. (ed.) Arctic geology and geophysics. Mem. Can. Soc. Petrol. Geol. 8, 331-348.

Håkansson, E. \& Stemmerik, L. 1989: Wandel Sea Basin - A new synthesis of the late Paleozoic to Tertiary accumulation in North Greenland. Geology 17, 683-686.

Håkansson, E., Heinberg, C. \& Stemmerik, L. 1981: The Wandel Sea Basin from Holm Land to Lockwood $\emptyset$, eastern North Greenland. Rapp. Gronlands geol. Unders. 106, 47-63.

Håkansson, E., Madsen, L. \& Pedersen, S. A. S. 1989: Geological investigations of Prinsesse Ingeborg Halvø, eastern North Greenland. Rapp. Grønlands geol. Unders. 145, 113118.

Nilsson, I. 1988: Carboniferous and Permian fusulinids on the Nordfjorden block, Spitsbergen (Svalbard). Unpublished thesis, Univ. Oslo, $143 \mathrm{pp}$.

Petryk, A. A. 1977: Upper Carboniferous (Late Pennsylvanian) microfossils from the Wandel Sea Basin, Peary Land, eastern North Greenland. Rapp. Gronlands geol. Unders. 85, 16-21.

Ross, C. A. \& Dunbar, C. O. 1962: Faunas and correlation of the late Paleozoic rocks of Northeast Greenland. Part II. Fusulinidae. Meddr Grønland 167(5), $55 \mathrm{pp}$.

Stemmerik, L. \& Håkansson, E. 1989: Stratigraphy and depositional history of the Upper Palaeozoic and Triassic sediments in the Wandel Sea Basin, eastern North Greenland. Rapp. Grønlands geol. Unders. 143, 20-44. 